\title{
Transcriptome profiling of malignant transformed rat hepatic stem-like cells by aflatoxin B1
}

\author{
L. YANG ${ }^{1}$, J. JI ${ }^{2}$, Z. CHEN ${ }^{3}$, H. WANG ${ }^{2, *}$, J. LI ${ }^{3, *}$ \\ ${ }^{1}$ School of Chemical Engineering and Technology, Tianjin University, Tianjin, China; ${ }^{2}$ School of Environmental Science and Technology, \\ Tianjin University, Tianjin, China; ${ }^{3}$ Institute of Hygiene and Environmental Medicine, Academy of Military Medical Science, Tianjin, \\ China \\ *Correspondence: : haiyongwang@tju.edu.cn (Haiyong Wang), junwen9999@163.com (Junwen Li)
}

\author{
Received June 11, 2013 / Accepted September 3, 2013
}

\begin{abstract}
Exposure to aflatoxins is strongly associated with hepatocellular carcinoma (HCC). Hepatic progenitor cells have been suggested to participate in the development of HCC. To further explore the molecular basis of aflatoxin-induced carcinogenesis, we utilized transcriptome profiles to examine the global gene expression alterations of malignant transformed rat hepatic stem-like cells. WB-F344 cells were treated with continuous exposure to AFB1 $(0.03,0.1$ and $0.2 \mu \mathrm{M})$, and gained certain characteristics of transformed cells identified by soft agar assay. Microarray analyses of the transformed cells found that 785, 625, and 751 differentially expressed genes were detected in each exposure group, respectively. Hierarchical Clustering revealed that the effect of 0.1 and $0.2 \mu \mathrm{M}$ exposure on the cells was conformable. Importantly, Gene Ontology analysis showed that malignant transformation of the hepatic stem-like cells was closely correlated to biological process, related to cell motion, cell adhesion, immune response and signal transduction. Accordingly, biological pathways was focused mainly on focal adhesion, regulation of actin cytoskeleton, ECM-receptor interaction, MAPK, TGF- $\beta$ and chemokine signaling pathway. A few genes involved in these pathways exhibited a dose response, including Cav2, Itgb3, $\mathrm{Ccl} 2$, Cx3cl1, Pdgfrb and Tmsb4x. These findings would contribute to a growing knowledgebase on the mechanism of aflatoxin-induced hepatocarcinogenesis.
\end{abstract}

Key words: Aflatoxin B1, hepatic progenitor cells, transcriptome profiles, malignant transformation

Hepatocellular carcinoma (HCC) is a common malignant tumor worldwide with extremely poor prognosis [1]. Environmental factors, mainly viral infection and dietary exposure to aflatoxins, have a strong association with HCC. Of the new HCC cases worldwide each year, about 4.6-28.2\% may be attributable to aflatoxin exposure, and occur mainly in sub-Saharan Africa, Southeast Asia, and China [2]. As one of the most important environmental toxins, aflatoxins are primarily produced by the fungi Aspergillus flavus and Aspergillus parasiticus, which colonize a wide variety of foodstuffs. Aflatoxin B1 (AFB1) is the most abundant and toxic member of the family, and is also considered to be the most potent hepatocarcinogen known. AFB1 has been classified by the International Agency for Research on Cancer as a group I carcinogen, based on sufficient evidence of carcinogenicity in humans and experimental animals [3]. Epidemiological studies showed that aflatoxins could induce a high incidence of hepatocarcinogenesis [4]. Further, high-frequency mutations of tumor suppressor gene p53 occurred in HCC related to aflatoxins [5]. Even so, the molecular mechanisms of aflatoxininduced hepatocarcinogenesis are still not well understood.

The liver is a silent organ in which hepatocytes, cholangioctyes, and progenitor cells all possess longevity. Since it is generally accepted that cell proliferation during carcinogen exposure is pivotal for 'fixation' of genotoxic injury into a heritable form, any proliferative cells in the liver can be susceptible to malignant transformation. However, it was indicated that the progenitor cells were activated when mature hepatocytes were damaged or inhibited in their replication by genotoxic carcinogens [6]. In addition, the hepatocytes became senescent owing to telomere shortening in some chronic liver diseases, in parallel to surveys from rodent models [7]. This makes it even more plausible that hepatic progenitor cells may be potential target cell for carcinogenesis. 
Hepatic progenitor cells are immature epithelial cells that reside in the biliary tree of the liver. These cells are capable of differentiating hepatocytes and biliary epithelial cells. The rat hepatic oval cells WB-F344, isolated from the liver of an adult male Fischer 344 rat, is considered to be an in vitro model of presumed hepatic progenitor cells [8]. In the present study, the molecular changes of hepatic oval cells during AFB1-induced malignant transformation were comprehensively investigated. Hepatic oval cells were transformed by continuous AFB1 exposure. Then, the global molecular changes were examined using Phalanx rat whole genome microarrays, which can study thousands of genes simultaneously. Genes with differential expression were then ranked and selected for further investigation using several statistical analyses. Better knowledge about oval cell changes in malignant transformation might provide more clues for further understanding molecular mechanisms of aflatoxin carcinogenesis, as well as seeking potential biomarkers.

\section{Materials and methods}

Cell lines and culture. Diploid WB-F344 cells, a rat nontumorigenic epithelial cell line, were kindly provided by Dr. Shen Hong (Central South University, Hunan, China). The cells were cultured in MEM medium (Gibco, Grand Island, NY, USA) supplemented with $10 \%$ fetal calf serum (Gibco), $100 \mathrm{U} / \mathrm{ml}$ penicillin and $100 \mathrm{mg} / \mathrm{ml}$ streptomycin at $37^{\circ} \mathrm{C}$ in a humidified atmosphere of $5 \% \mathrm{CO}_{2}$. Cells were trypsinized with $0.25 \%$ trypsin and split twice every week.

Cell transformation by AFB1 exposure. Cells were continuously exposed to vehicle control (0.5\% DMSO) or AFB1 $(0.03,0.1$ and $0.2 \mu \mathrm{M})$. In addition, cells were treated with fresh vehicle, AFB1, and medium every three days during this process. The procedures were repeated for 5 weeks. Cell culture-grade DMSO was used to make AFB1 stocks, and also used as vehicle in control cells.

Colony formation in soft agar. Cells exposed to AFB1 were assessed for anchoring-independent growth by colony formation in soft agar according to the method previously described [9]. Cells were suspended in MEM culture supplemented with $0.3 \%$ agar, then overlaid onto $0.6 \%$ agar medium with a density of $2 \times 10^{4} / \mathrm{ml}$. After 14-20 days' incubation, colony formation and enumeration were evaluated under a microscope (Leica, NY, USA).

Microarray analysis. Three arrays were carried out from each group. Total RNA was extracted using the RNeasy Mini Kit (Qiagen, Valencia, CA). The integrity of each RNA sample was determined using Agilent 2100 Bioanalyzer (Agilent, Foster City, CA). Following this, double-stranded cDNA was then prepared from total RNA using Superscript II reverse transcriptase (Invitrogen) and a T7 primer (Promega) for first strand synthesis, and DNA polymerase and ligase (Invitrogen) were used for second strand synthesis. Subsequently, fluorescent aRNA was prepared from cDNA using OneArray ${ }^{\circ}$ Amino Allyl aRNA Amplification Kit (Phalanx Biotech Group,
Taiwan) and Cy5 dyes (Amersham Pharmacia, Piscataway, NJ, USA). Fluorescent targets were suspended in hybridization buffer and hybridized to the Rat Whole Genome OneArray v1 (Phalanx Biotech Group, Taiwan) using Phalanx Hybridization System. After $16 \mathrm{~h}$ hybridization at $50^{\circ} \mathrm{C}$, non-specific binding targets were removed via three different washing steps (Wash I: $42^{\circ} \mathrm{C}$ for $5 \mathrm{~min}$; Wash II: $42^{\circ} \mathrm{C}$ for $5 \mathrm{~min}$, then $25^{\circ} \mathrm{C}$ for $5 \mathrm{~min}$; Wash III: rinse 20 times), and the slides were dried by centrifugation and scanned on an Axon 4000B scanner (Molecular Devices, Sunnyvale, CA, USA). The intensities of each probe were obtained by GenePix 4.1 software (Molecular Devices). The raw intensity of each spot was loaded into the Rosetta Resolver System ${ }^{\bullet}$ (Rosetta Biosoftware) for data analysis. The error model of the Rosetta Resolver System ${ }^{\circ}$ removed both systematic and random errors from the data. Probes with background signals were filtered out and probes that passed the criteria were normalized by $50 \%$ median scaling normalization method. The fold changes of genes were calculated by dividing the normalized signal intensities of genes in AFB1-treated cells by those in vehicle control. The differentially expressed genes (DEGs) were identified when fold changes were $\geq 1.5$ or $\leq-1.5$ with $p$-value $<0.05$.

Analysis of differentially expressed genes. Analysis of these DEGs was carried out by means of hierarchic gene clustering with the use of Cluster 3.0 (open source 2006) and Treeview (Stanford University Labs) software. In order to analyze the mechanism of AFB1-induced carcinogenesis, DEGs were further assigned to an appropriated category according to its main cellular function. The necessary information to categorize DEGs was obtained from several databases, mainly DAVID Bioinformatics Resources 6.7 [10, 11], Gene Ontology [12], KEGG pathway [13].

Quantitative real-time PCR (qRT-PCR). The mRNA expression for the genes of interest was analyzed via qRTPCR. Total RNA was reverse transcribed into cDNA with the RT reagent kit (Takara, Dalian, China). The samples were prepared using Fast SYBR Green Master Mix (Roche Applied Science, Indianapolis, IN). qRT-PCR analysis was then performed using the ABI 7300 Real-Time PCR instrument (Applied Biosystems, USA) and cycled as follows: 95 ${ }^{\circ} \mathrm{C} 1 \mathrm{~min}$, then 40 cycles of $95^{\circ} \mathrm{C} 30 \mathrm{~s}$ followed by $60^{\circ} \mathrm{C}$ for $1 \mathrm{~min}$. Each sample was analyzed in triplicate. GADPH was set as an endogenous control for mRNA, and nonspecific amplification was excluded by performing qRT-PCR in the absence of target cDNA. The specific primer sequences were synthesized by Invitrogen and listed in Table 1. The relative expression levels of these genes were normalized to that of GADPH using the $2^{-\triangle \Delta C T}$ cycle threshold method. Notably, the amplification efficiencies of the targets and references were approximately equal.

\section{Results}

Gene expression alteration during AFB1-induced malignant transformation. In the study, WB-F344 cells treated 


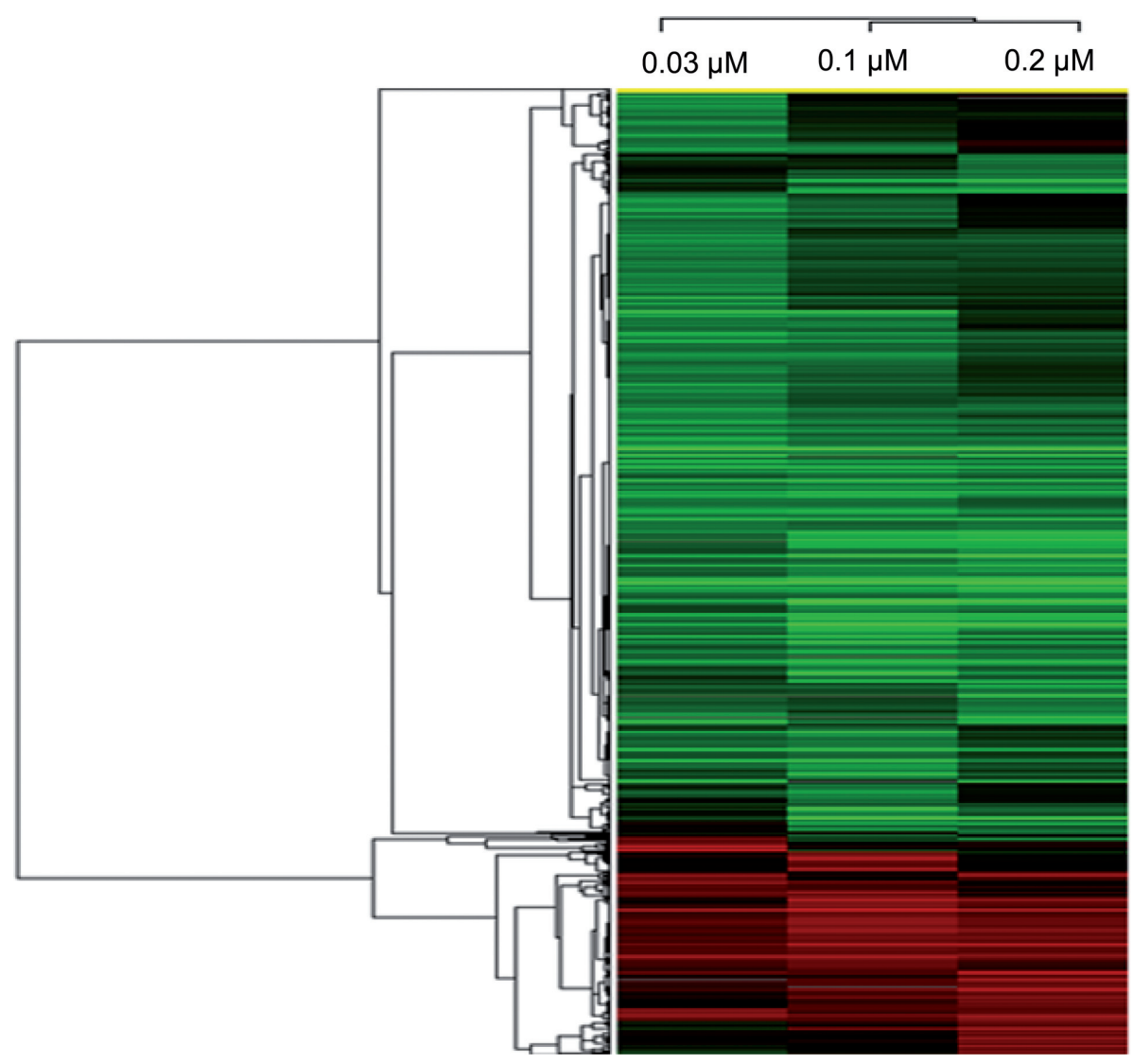

Figure 1. Hierarchical Clustering of DEGs responsive to $0.03,0.1$ and $0.2 \mu \mathrm{M}$ AFB1.

DEGs were identified with 1.5 -fold change cut-off and $p$-value $<0.05$ in comparison to vehicle control. The $y$-aixs of the dendrogram represented the DEGs and the corresponding expression level displayed in green for down-regulation, red for up-regulation, and black for insignificant change in gene expression.

with AFB1 gained certain characteristics of transformed cells. The transformed cells could form colonies in soft agar, and the frequencies of colony formation were $0.8 \%, 1.3 \%$, and $2 \%$ in $0.03,0.1$, and $0.2 \mu \mathrm{M}$, respectively, but WB-F344 cells could not grow in soft agar. It indicated that the transformed cells had slight ability of anchoring-independent growth. Gene expression alteration during malignant transformation of rat hepatic oval cells was investigated. Hierarchical clustering was used to aid in the visualization and biological interpretation of this extensive data set, and in particular, to identify correlated expression pattern (Fig.1). Transcriptomic profiling showed different gene expression patterns in each exposure group and it was found that response to AFB1 in 0.1 and $0.2 \mu \mathrm{M}$ had more similarity. Exposure to $0.03 \mu \mathrm{M}$ AFB1 resulted in the greatest number (785) of DEGs compared to the control. Exposure to $0.1,0.2 \mu \mathrm{M}$ AFB1 resulted in 625 and 751 DEGs, respectively.

KEGG pathway and GO analysis. The biological effects of AFB1 on hepatic progenitor cells are of interest to better understand aflatoxin-induced carcinogenesis. GO and KEGG analysis assisted us in determining these biological effects us-
Table 1. Primer sequences for the quantitative real time RT-PCR used in this study.

\begin{tabular}{llll}
\hline Gene & Accession No. & & Primer sequence $\left(5^{\prime} \rightarrow 3^{\prime}\right)$ \\
\hline Cdx2 & NM_023963 & F & ACCTTCTGGACAAGGACGTGAGCAT \\
& & R & ACCATTGAGGCCGT GGGCTA \\
Pla1a & NM_138882 & F & GGGGACATGCTTCTGGTTGT \\
& & R & CCTAATGCCCTGAATCCAT \\
Tspan12 & NM_001015026 & F & ATGGCCAGAGAAGATTCCG \\
& & R & CACAGTATCCCAGCATTCC \\
Lpl & NM_012598 & F & ATGGAGAGCAAAGCCCTGC \\
& & R & GTCACCGTCCATCCATGGA \\
Gapdh & NM_017008 & F & GACTCTACCCACGGCAAGT \\
& & R & GCGGAGATGATGACCCTT \\
\hline
\end{tabular}

ing genes with significant differential expression. According to their functional categories and relatedness, DEGs were classified (Table 2) and mainly involved in vesicle-mediated transport, cell motion, cell adhesion, signal transduction, as well as immune response. Shockingly, only DEGs in the lowest 
Table 2. GO annotations for DEGs responsive to $0.03,0.1$ and $0.2 \mu \mathrm{M}$ AFB1.

\begin{tabular}{|c|c|c|c|c|c|c|}
\hline \multirow[t]{2}{*}{ Biological Process } & \multicolumn{2}{|c|}{$0.03 \mu \mathrm{M}$} & \multicolumn{2}{|c|}{$0.1 \mu \mathrm{M}$} & \multicolumn{2}{|c|}{$0.2 \mu \mathrm{M}$} \\
\hline & $\begin{array}{c}\text { Enrichment } \\
\text { scores }\end{array}$ & $\begin{array}{l}\text { Gene } \\
\text { count }\end{array}$ & $\begin{array}{c}\text { Enrichment } \\
\text { scores }\end{array}$ & $\begin{array}{l}\text { Gene } \\
\text { count }\end{array}$ & $\begin{array}{c}\text { Enrichment } \\
\text { scores }\end{array}$ & $\begin{array}{l}\text { Gene } \\
\text { count }\end{array}$ \\
\hline Positive regulation of transport & 2.299 & 25 & & & & \\
\hline Vesicle-mediated transport & 2.714 & 36 & 1.962 & 26 & 1.723 & 31 \\
\hline Amine transport & & & 1.479 & 13 & & \\
\hline Cell motion & 1.869 & 23 & 5.228 & 32 & 3.448 & 34 \\
\hline Regulation of cell motion & 1.869 & 22 & 1.733 & 12 & & \\
\hline Chemotaxis & 3.561 & 53 & 1.523 & 25 & 2.071 & 31 \\
\hline Response to oxidative stress & 3.556 & 33 & & & & \\
\hline Response to wounding & 3.308 & 42 & & & 4.407 & 50 \\
\hline Regulation of cell death & 2.664 & 46 & & & & \\
\hline Cell death & 1.980 & 25 & & & & \\
\hline Regulation of cell adhesion & 2.611 & 17 & 2.112 & 11 & 1.807 & 14 \\
\hline Regulation of cell cycle & 2.492 & 11 & 2.930 & 36 & & \\
\hline Regulation of lipid storage & 1.684 & 5 & 2.431 & 4 & & \\
\hline Immune response & 1.477 & 24 & 1.432 & 29 & & \\
\hline Antigen processing and presentation & 1.691 & 6 & 1.928 & 6 & 1.815 & 10 \\
\hline Vasculature development & 2.920 & 20 & 3.557 & 22 & 2.584 & 20 \\
\hline Tissue morphogenesis & 3.136 & 39 & 3.338 & 35 & 2.104 & 33 \\
\hline System development & & & 1.773 & 11 & 1.641 & 13 \\
\hline Cellular component orgnization & 1.745 & 29 & & & 1.493 & 41 \\
\hline Cell-cell signaling & 1.652 & 30 & 1.756 & 24 & & \\
\hline Regulation of signal transduction & 1.400 & 6 & & & 1.692 & 15 \\
\hline Ossification & 2.021 & 20 & 1.735 & 10 & & \\
\hline Growth & & & 1.670 & 20 & & \\
\hline Cytoskeleton organization & 1.534 & 36 & 1.471 & 21 & & \\
\hline
\end{tabular}

DEGs were identified with 1.5 -fold change cut-off and $p$-value $<0.05$ in comparison to vehicle control. Shown were GO biological processes that significantly overrepresented (enrichment score $\geq 1.3$ ) in the AFB1-treated groups. Enrichment scores represented the overall importance of biological processes. Enrichment scores of 1.3 was equivalent to non-log scale 0.05 . Gene count represented the number of DEGs participated in the biological process.

dose notably attributed to cell death. Further, the biological pathways were functionally categorized and their distribution by AFB1 dose was found in Fig.2. These biological pathways, including focal adhesion, pathways in cancer, regulation of actin cytoskeleton, TGF-beta signaling pathway, ECM-receptor interaction and chemokine signaling pathway, were all significantly impacted by different doses. Moreover, other biological pathways were only significantly impacted by special dose. It was found that only wnt signaling pathway and adherens junction were significantly impacted in $0.03 \mu \mathrm{M}$; cytokinecytokine receptor interaction only occurred in $0.1 \mu \mathrm{M}$; and only hedgehog signaling pathway was deregulated in $0.2 \mu \mathrm{M}$. A dose-response curve in regard to the number of genes that were differentially expressed was anticipated, although several pathways did not follow the expected pattern. For example, focal adhesion showed 21 (in $0.03 \mu \mathrm{M}), 17$ (in $0.1 \mu \mathrm{M}$ ) and surprising 19 DEGs (in $0.2 \mu \mathrm{M}$ ), respectively. A partial list of genes exhibiting differential expression categorized by their KEGG biological pathways is presented in Table 3. Only a few genes in these pathways exhibiting monotonically decreasing (Cav2, Itgb3, Ccl2 and Cx3cl1) or increasing trends (Pdgfrb and Tmsb4x) were also observed.

These KEGG pathways were not independent of one another, and their cross-talk was illustrated in Fig.3. We found that not all pathways were equally informative. MAPK signaling pathway, regulation of action cytoskeleton and pathways in cancer formed a central node in the exposure group of $0.03 \mu \mathrm{M}$; focal adhesion and pathways in cancer were dominated in $0.1 \mu \mathrm{M}$ group; focal adhesion, MAPK signaling pathway, and regulation of actin cytoskeleton were indicated to be vital in $0.2 \mu \mathrm{M}$ group.

Validation of DEGs by qRT-PCR. To confirm the mRNA expression of microarray data, 4 commonly expressed genes (Cdx2, Pla1a, Tspan12 and Lpl) were chosen using qRT-PCR. Expression changes of these selected genes were compared through microarray and qRT-PCR, presented in Fig.4. These selected genes were in good agreement for consistency of response to AFB1, and their expression showed similar patterns 


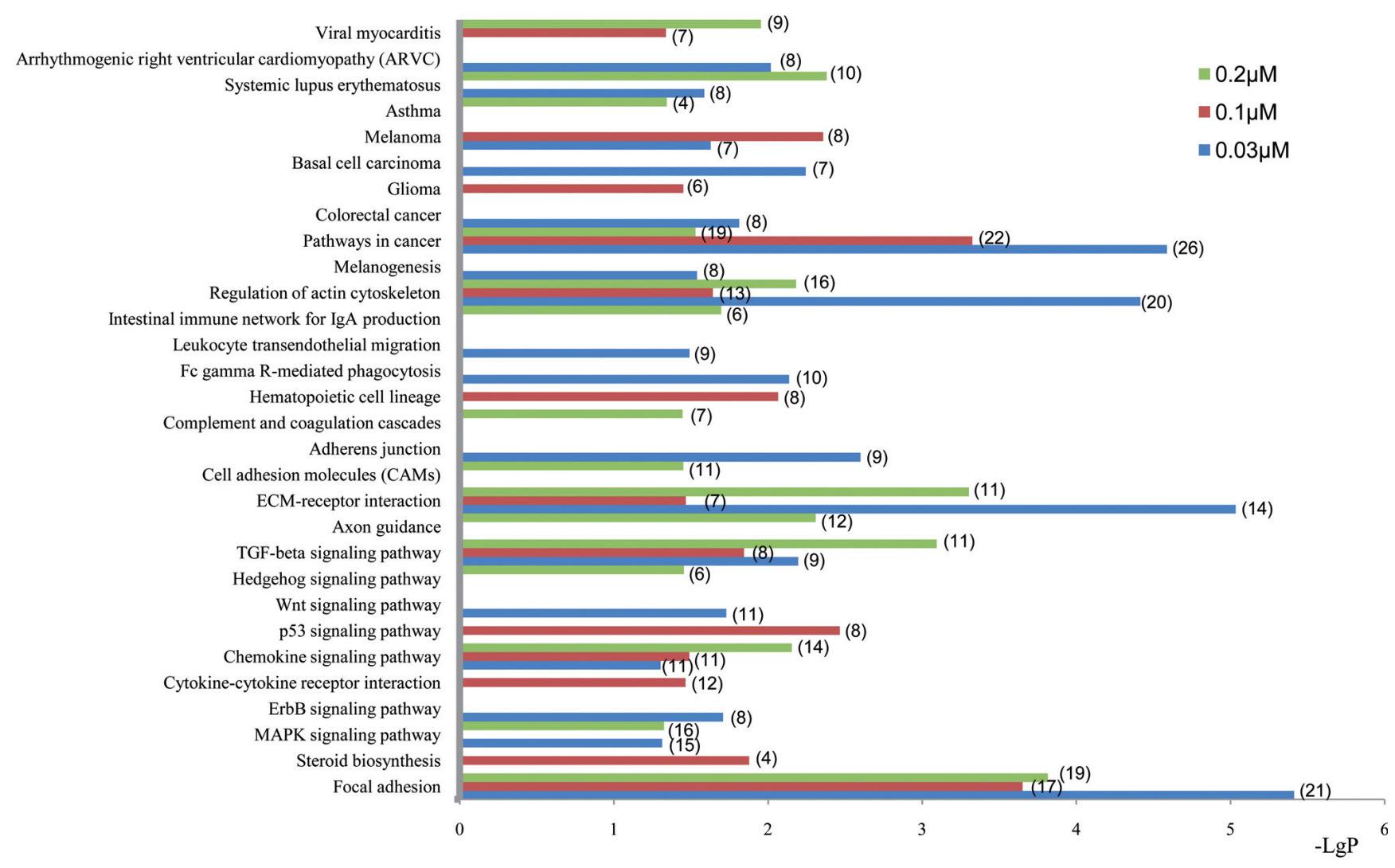

Figure 2. KEGG biological pathways responsive to $0.03,0.1$ and $0.2 \mu \mathrm{M}$ AFB 1 .

Shown were biological pathways that significantly overrepresented $(p<0.05)$ in the AFB1-treated groups. The bar graph indicated the negative logarithm of p-value of these biological pathways. The number of DEGs participated in the pathway was given in parenthesis. DEGs were identified with 1.5 -fold change cut-off and $p$-value $<0.05$ in comparison to vehicle control.

in the two platforms. In other words, the qRT-PCR data supported the dose response trend depicted by the array data.

\section{Discussion}

Hepatic progenitor cells are facultative stem cells in liver, which participate in a range of human liver diseases, including HCC. There is increased evidence to suggest that these cells are the cellular targets for transformation in the development of HCC. Hepatic progenitor cells c-Kit $\mathrm{CD} 29^{+} \mathrm{CD} 49 \mathrm{f}^{+/ l o w} \mathrm{CD} 45^{-}$ Ter-119- were found to exhibit the histologic features of HCC after transduction of Bmil or $\beta$-catenin, which further implied that dysregulated self-renewal of hepatic progenitor cells served as an early event in hepatocarcinogensis [14]. Besides, it was found that the deletion of p53 in CD133 ${ }^{+} \mathrm{LC}$-forming cells with stem cell-like capacity also resulted in the formation of tumors with some characteristics of HCC [15], as well as transformation of p53-null hepatic progenitor cells that gave rise to HCC [16].

Chronic exposure to aflatoxins is a major risk factor for HCC. To better understand the mechanism of actin in aflatoxin-induced carcinogenesis, hepatic oval cells were transformed by continuous AFB1 exposure. Then, we have identified the gene expression profiles of the transformed cells using whole rat genome microarray. Triplicate assays were performed to avoid the error rates. Microarray study with statistical analysis showed that 785, 625 and 751 genes changed their expression in the exposure dose of $0.03,0.1$ and $0.2 \mu \mathrm{M}$, respectively. We analyzed these genes in KEGG pathways and GO categories. These interesting genes are related to several pathways, such as focal adhesion, pathway in cancer and ECM-receptor interaction, which corresponded well with enriched GO categories. Since KEGG pathways provide more biological information in that they show molecular interactions, further analyses focused on it.

Focal adhesion. Focal adhesion is structural links between the extracellular matrix and actin cytoskeleton, as well as important sites of signal transduction pathways leading to various biological processes. Aberrant expression and altered functions of focal adhesion genes contribute to adverse tumor behavior. Focal adhesion genes have been shown to play critical roles in HCC [17]. In this study, Cav2 and Parvb were down-regulated in all doses (the maximum decline of 7.17 and 1.9-fold, respectively), and the expression of Pxn was decreased in 0.1 
Table 3. Biological pathways of DEGs responsive to $0.03,0.1$ and $0.2 \mu \mathrm{M}$ AFB1.

\begin{tabular}{|c|c|c|c|c|}
\hline \multirow{2}{*}{ Gene } & \multirow{2}{*}{ Description } & \multicolumn{3}{|c|}{ Fold change } \\
\hline & & $0.03 \mu \mathrm{M}$ & $0.1 \mu \mathrm{M}$ & $0.2 \mu \mathrm{M}$ \\
\hline \multicolumn{5}{|c|}{ Focal adhesion } \\
\hline Cav2 & caveolin 2 & -7.170 & -4.275 & -3.528 \\
\hline Ccnd2 & cyclin D2 & & & 2.082 \\
\hline Ctnnb1 & catenin, beta 1 & -1.931 & & \\
\hline Met & met proto-oncogene & -2.507 & -1.715 & -2.464 \\
\hline Parvb & parvin, beta & -1.784 & -1.896 & -1.767 \\
\hline Pxn & paxillin & & -1.651 & -1.809 \\
\hline Spp1 & secreted phosphoprotein 1 & & -3.425 & -4.579 \\
\hline Thbs1 & thrombospondin 1 & -3.019 & -3.027 & -3.560 \\
\hline Tnc & tenascin $\mathrm{C}$ & -2.018 & & \\
\hline \multicolumn{5}{|c|}{ ECM-receptor interaction } \\
\hline Col3a1 & collagen, type III, alpha 1 & -5.049 & -3.242 & -8.000 \\
\hline Itgb3 & integrin, beta 3 & -2.402 & -2.069 & -1.940 \\
\hline Colla1 & collagen, type I, alpha 1 & -2.288 & & -2.003 \\
\hline Col5a2 & collagen, type V, alpha 2 & -2.130 & -1.925 & -1.974 \\
\hline Dag1 & dystroglycan 1 & -2.045 & & -1.799 \\
\hline $\mathrm{Cd} 47$ & Cd47 molecule & -1.748 & & \\
\hline Col6a2 & collagen, type VI, alpha 2 & 1.963 & & \\
\hline Itga7 & integrin, alpha 7 & 2.624 & & 1.767 \\
\hline $\mathrm{Cd} 36$ & CD36 molecule & 2.979 & 2.170 & 2.932 \\
\hline \multicolumn{5}{|c|}{ Pathways in cancer } \\
\hline Bid & $\mathrm{BH} 3$ interacting domain death agonist & -1.799 & & -1.804 \\
\hline $\mathrm{Cbl}$ & Cas-Br-M (murine) ecotropic retroviral transforming sequence & -1.837 & & \\
\hline Ccnd1 1 & cyclin D1 & & -1.824 & \\
\hline Crk & v-crk sarcoma virus CT10 oncogene homolog (avian) & -2.313 & & \\
\hline Egfr & epidermal growth factor receptor & & 2.066 & \\
\hline $\operatorname{Eg} \ln 3$ & EGL nine homolog 3 (C. elegans) & & -1.804 & \\
\hline Fas & Fas (TNF receptor superfamily, member 6) & & -1.741 & \\
\hline Gli2 & GLI family zinc finger 2 & -1.924 & & \\
\hline Igf1 & insulin-like growth factor 1 & & -1.844 & \\
\hline Plcg2 & phospholipase $\mathrm{C}$, gamma 2 & -1.818 & -1.644 & -1.753 \\
\hline Pml & promyelocytic leukemia & -1.856 & & -1.717 \\
\hline Runx1 & runt-related transcription factor 1 & & -2.249 & -2.304 \\
\hline Runx1t1 & runt-related transcription factor 1 ; translocated to, 1 (cyclin D-related) & & -2.031 & -3.065 \\
\hline Tcf7 & transcription factor 7, T-cell specific & -2.565 & -2.068 & -2.104 \\
\hline Wnt4 & wingless-type MMTV integration site family, member 4 & & 1.824 & 1.621 \\
\hline Wnt5a & wingless-type MMTV integration site family, member 5A & -1.880 & & -1.646 \\
\hline Wnt7a & wingless-type MMTV integration site family, member 7A & & 1.865 & 1.728 \\
\hline \multicolumn{5}{|c|}{ Regulation of actin cytoskeleton } \\
\hline Actn 1 & actinin, alpha 1 & -1.754 & & \\
\hline Bdkrb1 & bradykinin receptor $\mathrm{B} 1$ & & & -1.903 \\
\hline Gsn & gelsolin & -1.844 & & -1.681 \\
\hline Msn & moesin & -1.968 & -1.831 & \\
\hline Myh9 & myosin, heavy chain 9 , non-muscle & -1.814 & -1.765 & -1.682 \\
\hline Pdgfc & platelet derived growth factor $\mathrm{C}$ & -2.282 & & -1.979 \\
\hline Pdgfrb & platelet derived growth factor receptor, beta polypeptide & -2.126 & -2.430 & -3.541 \\
\hline Tmsb4x & thymosin beta 4 , X-linked & 3.755 & 47.144 & 79.617 \\
\hline
\end{tabular}




\begin{tabular}{|c|c|c|c|c|}
\hline \multirow{2}{*}{ Gene } & \multirow{2}{*}{ Description } & \multicolumn{3}{|c|}{ Fold change } \\
\hline & & $0.03 \mu \mathrm{M}$ & $0.1 \mu \mathrm{M}$ & $0.2 \mu \mathrm{M}$ \\
\hline \multicolumn{5}{|c|}{ TGF-beta signaling pathway } \\
\hline Inhbb & inhibin beta-B & -2.169 & -1.887 & -1.990 \\
\hline Ppp2r1a & protein phosphatase 2 (formerly $2 \mathrm{~A}$ ), regulatory subunit $\mathrm{A}$, alpha isoform & -1.948 & & \\
\hline Bmp2 & bone morphogenetic protein 2 & -2.626 & -2.417 & -2.894 \\
\hline Rbl1 & retinoblastoma-like 1 (p107) & -1.733 & -1.622 & -1.747 \\
\hline Bmp6 & bone morphogenetic protein 6 & -1.763 & & -1.785 \\
\hline Inhba & inhibin beta-A & & -2.433 & -3.040 \\
\hline Bmpr1b & bone morphogenetic protein receptor, type IB & & 1.871 & 1.873 \\
\hline Id 4 & inhibitor of DNA binding 4 & & 1.866 & 1.598 \\
\hline Fst & follistatin & & & -2.696 \\
\hline Inhbe & inhibin beta $\mathrm{E}$ & & & -1.837 \\
\hline Ltbp1 & latent transforming growth factor beta binding protein 1 & & -1.723 & -2.069 \\
\hline \multicolumn{5}{|c|}{ Chemokine signaling pathway } \\
\hline Cxcl1 & chemokine (C-X-C motif) ligand 1 & -1.742 & -1.967 & -1.847 \\
\hline $\mathrm{Ccl} 2$ & chemokine (C-C motif) ligand 2 & -1.746 & -2.141 & -3.613 \\
\hline $\mathrm{Cx} 3 \mathrm{cl} 1$ & chemokine (C-X3-C motif) ligand 1 & -1.667 & -1.753 & -1.957 \\
\hline Ccl5 & chemokine (C-C motif) ligand 5 & -1.666 & & -2.145 \\
\hline Cxcl12 & chemokine (C-X-C motif) ligand 12 & -1.728 & & -1.746 \\
\hline Cxcl10 & chemokine (C-X-C motif) ligand 10 & -1.670 & -2.310 & -1.638 \\
\hline Cxcl13 & chemokine (C-X-C motif) ligand 13 & -1.734 & -6.298 & -3.803 \\
\hline Xcr1 & chemokine ( $\mathrm{C}$ motif) receptor 1 & & & 2.354 \\
\hline Foxo3 & forkhead box O3 & -1.920 & & \\
\hline \multicolumn{5}{|c|}{ Wnt signaling pathway } \\
\hline Wnt5a & wingless-type MMTV integration site family, member $5 \mathrm{~A}$ & -1.880 & & \\
\hline Tcf7 & transcription factor 7 , T-cell specific & -2.565 & & \\
\hline Wif1 & Wnt inhibitory factor 1 & -6.769 & & \\
\hline Fzd5 & frizzled homolog 5 (Drosophila) & -1.813 & & \\
\hline Fzd4 & frizzled homolog 4 (Drosophila) & -1.840 & & \\
\hline Fosl1 & fos-like antigen 1 & -1.988 & & \\
\hline \multicolumn{5}{|c|}{ MAPK signaling pathway } \\
\hline Gna12 & guanine nucleotide binding protein, alpha 12 & -2.020 & & \\
\hline Fgf13 & fibroblast growth factor 13 & -1.982 & & -2.301 \\
\hline Fgf12 & fibroblast growth factor 12 & 5.848 & & \\
\hline Fgf21 & fibroblast growth factor 21 & 1.814 & & \\
\hline Flnc & filamin C, gamma & -1.648 & & -1.751 \\
\hline Dusp4 & dual specificity phosphatase 4 & -1.952 & & -1.833 \\
\hline Rasgrp3 & RAS guanyl releasing protein 3 & 1.999 & & 2.490 \\
\hline Pla2g2a & phospholipase A2, group IIA & -3.320 & & -10.770 \\
\hline Mapk8 & mitogen-activated protein kinase 8 & -2.380 & & \\
\hline Fgf7 & fibroblast growth factor 7 & & & 2.275 \\
\hline Ddit3 & DNA-damage inducible transcript 3 & & & 2.221 \\
\hline Gadd45a & growth arrest and DNA-damage-inducible, alpha & & & 2.516 \\
\hline
\end{tabular}

and $0.2 \mu \mathrm{M}$ (-1.65 and -1.81-fold, respectively). Cav1 forms oligomeric complexes with Cav2, which is essential for the coat structure of caveolae. The down-regulation of Cav1 and Cav2 was found in various types of primary tumors and cancer cells
$[18,19]$. Cav2 tansfection in HepG2 cells caused reduction in cell proliferation and growth, indicating a certain inhibition for tumors. Parvb is an ILK-binding protein that is involved in the regulation of cell anchorage. Its expression level was markedly 

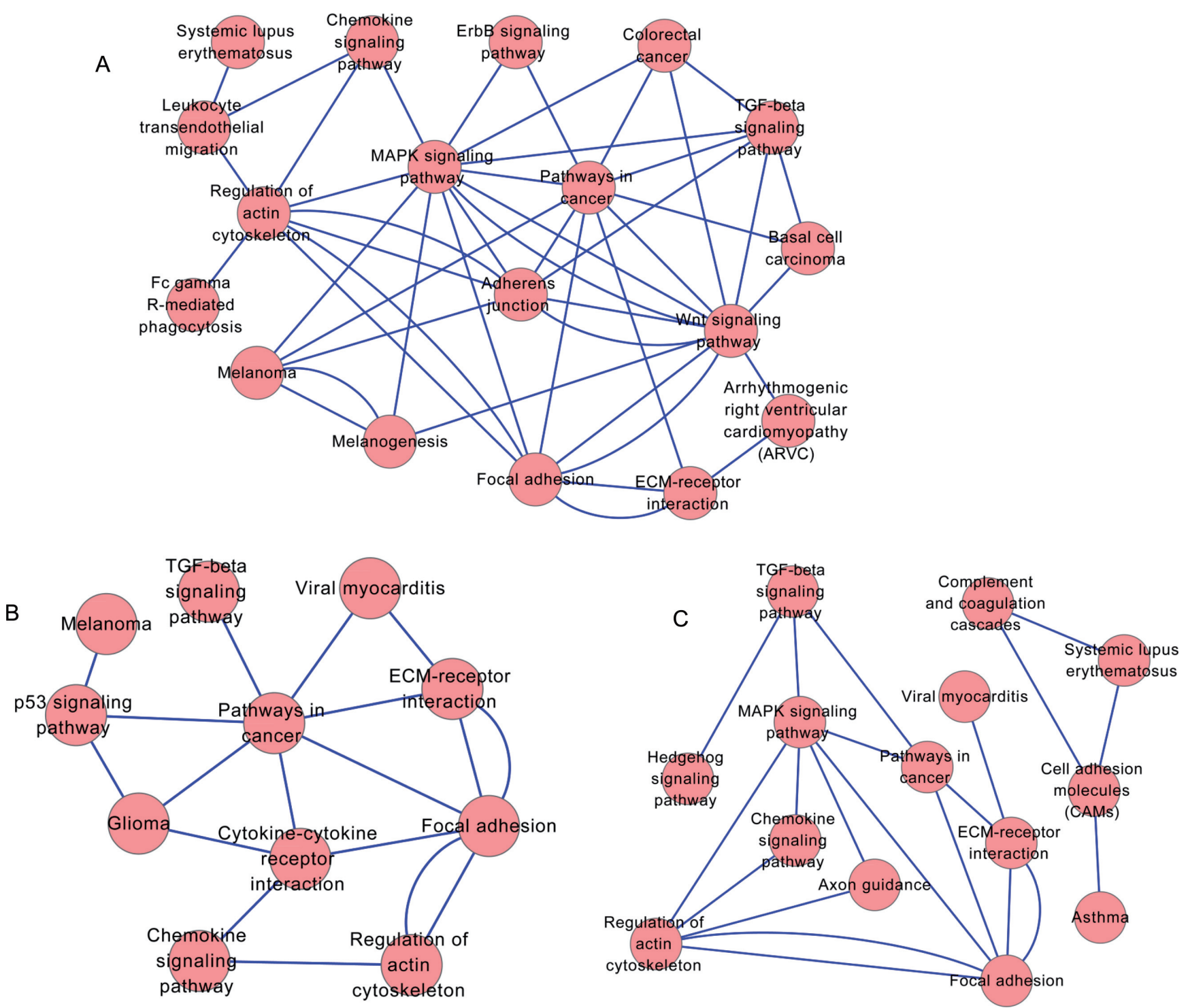

Figure 3. Cross-talk of KEGG biological pathways responsive to 0.03 (A), 0.1 (B) and $0.2 \mu \mathrm{M}$ (C) AFB1. Shown were the relationship of these biological pathways that significantly overrepresented $(p<0.05)$ in the AFB1-treated groups. Solid lines indicated interactions between the two biological pathways.

down-regulated in several advanced breast tumors [20]. Pxn is associated with cell spreading and motility. Absence or low levels of Pxn expression have been demonstrated in certain human lung cancers [21]. Further, the decrease level of Pxn correlated with the grading of tumors [22].

Regulation of actin cytoskeleton. The actin cytoskeleton is the cellular engine that drives cell motility downstream of a complex signal transduction cascade. Deregulation of the actin system is linked to the invasive and metastatic phenotypes of malignant cancers [23]. Gsn is a ubiquitous actin-binding protein and contributes to apoptosis as the downstream common effector. Gsn was down-regulated in many types of human malignancies [24]. In this study, decreases in Gsn expression were observed at the exposure of 0.03 and $0.2 \mu \mathrm{M}$. High expression of Tmsb4 $\mathrm{x}$ has been implicated in multiple cancers, including HCC [25]. Tmsb4x overexpression further rendered cancer cells more resistance to apoptosis triggered by FasL [26]. Consistent with this, Tmsb4x expression was more elevated as exposure dose increasing, up to 79 -fold in the highest dose.

TGF- $\beta$ signaling pathway. Alterations in the TGF- $\beta$ signaling pathway, including mutation or deletion of members of the signaling pathway and resistance of TGF- $\beta$-mediated inhibition of proliferation were frequently observed in human 


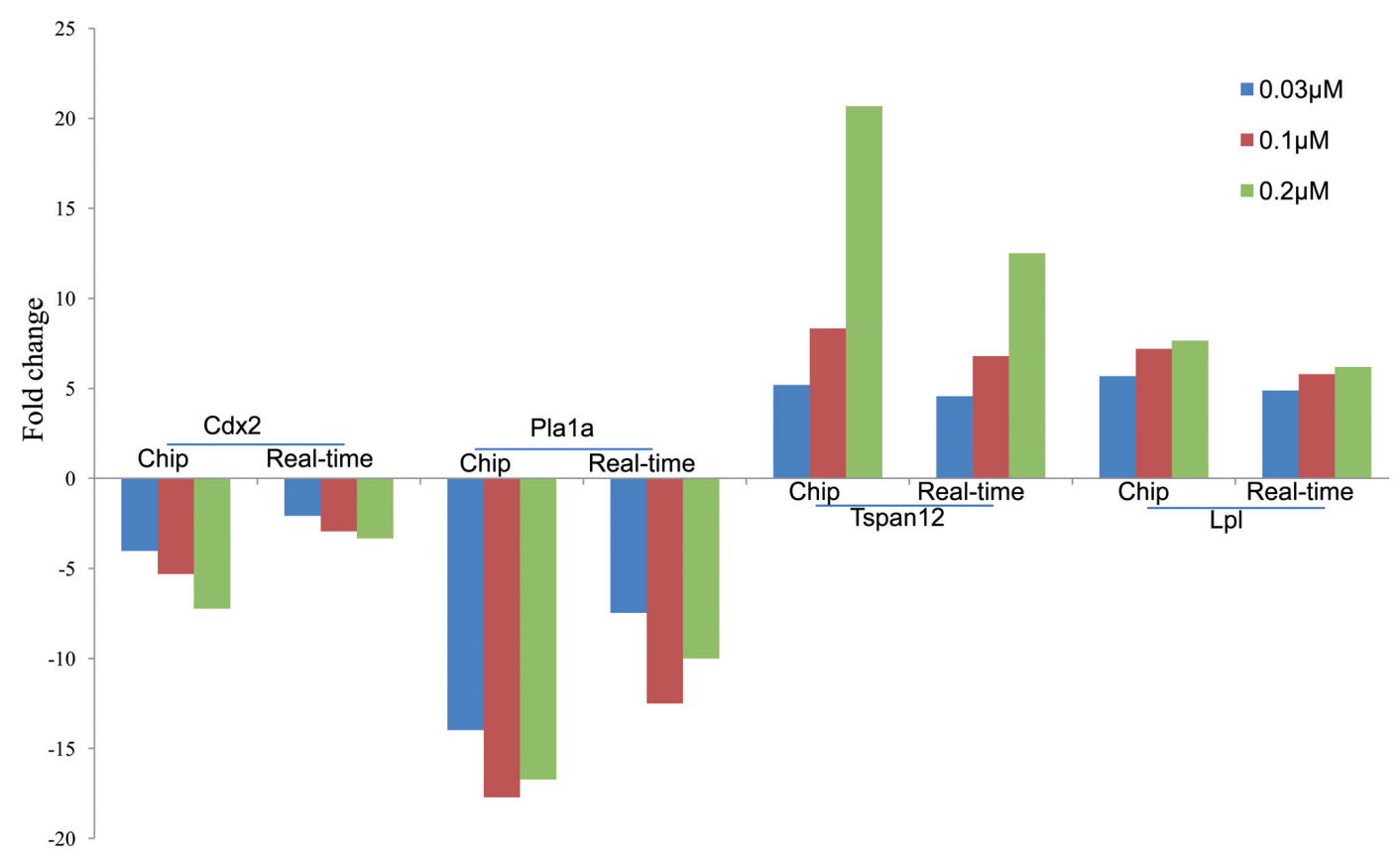

Figure 4. Comparison of gene differential expression between qRT-PCR and microarray.

Shown were the fold changes of the genes obtained by QRT-PCR and microarray analysis. The changes in gene expression were represented as fold changes of AFB1-treated relative to vehicle control.

cancers [27]. In the study, the expression of Ltbp1 was significantly down-regulated, while Id4 expression was up-regulated in 0.1 and $0.2 \mu \mathrm{M}$. Ltbp 1 is part of the latent TFG- $\beta$ complex and involved in the cellular assembly, secretion and activation of TFG- $\beta 1$. It was found that the expression level of Ltbp1 was decreased in HCC [28]. Different expression of Id4 has been shown in several types of human cancers $[29,30]$. The role of Thbs 1 in tumor progression is complex and controversial. High levels of Thbs1 could inhibit tumor growth, while anti-sense inhibition of Thbs1 in certain tumors also inhibited growth [31]. Bmp family also played a dual role in tumorigenesis [32]. In addition, it has been investigated that Inhba and Inhbe were down-regulated in chemically induced hepatocarcinogenesis [33]. In the study, we observed a dose-dependent decrease in Thbs1, Bmp2 and Bmp6 expression, as well as Inhba, Inhbb and Inhbe.

MAPK signaling pathway. Mitogen-activated protein kinases (MAPK) or the signaling cascades that regulate them play an important role in a variety of cellular responses, including cell proliferation, differentiation, and apoptosis. It is known that deregulation of MAPK signaling is the most common alteration in various types of human cancers, including HCC $[34,35]$. The Jun $\mathrm{N}$-terminal kinases (JNK) are a subgroup of MAPKs, and consist of Mapk8 (Jnk1), Mapk9 (Jnk2) and Mapk10 (Jnk3). It was reported that Jnk deficiency in hepatic nonparenchymal cells reduced DENinduced HCC rather than in hepatocytes, which indicated that the protumorigenic function of Jnk might be localized to nonparenchymal cells [36]. In the present study, Mapk8 was down-regulated only at the lowest dose, and Mapk10 was up-regulated only at the highest dose. However, we did not make reasonable explanations for their expression changes. RAS guanyl releasing proteins (Rasgrp) mediates activation of the Ras oncogene through the transfer of guanosine [37]. Increases in Rasgrp 2 and Rasgrp 3 expression were observed, the former 1.65 -fold at $0.2 \mu \mathrm{M}$ and the latter 2 - and 2.49 -fold at 0.03 and $0.2 \mu \mathrm{M}$, respectively. Dual-specificity protein phosphatases (Dusp) can dephosphorylate both phosphor-threonine and phosphor-tyrosine residues. Dusp4 was significantly down-regulated in our study, which was consistent with the expression in HepG2 cells [38]. Genetic evidence for the Pla2g2a protecting against tumorigenesis has been demonstrated [39], and the greatest decreased expression was detected in $0.2 \mu \mathrm{M}$ (-8-fold).

Other pathways and genes. ECM-receptor interaction leads to a direct or indirect control of cellular activities, such as adhesion, migration, differentiation, proliferation, and apoptosis. Multiple transcripts involved in ECM-receptor interaction were significantly down-regulated, including collagens (Col1a1, Col5a2, Col3a1 and Col6a2), as well as Itgb3. It was found that up-regulation of the expression of collagens was certainly associated with metastasis suppression [40]. Integrins are cell surface receptors mediating cell-matrix and cell-cell adhesion. Itgb3 was significantly down-regulated in HCC, and its overexpression resulted in apoptosis and inhibition of clonogenic survival [41]. 
Chemokines play a central role in many biological events, including tumors. Cxcl12 was relevant in HCC occurrence and development, and its down-expression was detected in HCC [42]. Cx3cll was observed to elicit tumor-specific cytotoxic T cells and an increased production of IL- 2 and IFN- $\gamma$ capable of inhibiting tumor growth [43]. Overexpression of Cxcl10 was attributed to its ability to decrease tumor angiogenesis [44]. In the study, Cx3cl1 and Cxcl10 were found to be significantly down-regulated in all doses. Surprisingly, Cxcl12 was also down-regulated in 0.03 and $0.2 \mu \mathrm{M}$, with no observable change in $0.1 \mu \mathrm{M}$.

In addition, differentially expressed genes associated with carcinogenesis included Wnt4, Wnt7a, Tcf7, and Runx1. Up-regulation of Wnt 4 and Wnt7a was observed at 0.1 and $0.2 \mu \mathrm{M}$, respectively. Tcf7 was down-regulated in all treatments, and Runx1 was also down-expressed in 0.1 and $0.2 \mu \mathrm{M}$. Over-expression of Wnt 4 and Wnt7a, which lead to increased migration and invasion capacity, was demonstrated in many types of cancers, including HCC $[45,46]$. Mice missing Tcf7 (Tcf1 protein) developed intestinal and mammary adenomas, which suggested that Tcf7 might cooperate with Apc to suppress malignant transformation of epithelial cells [47]. Deficient function of Runx1 is causally related to development and progression of gastric cancer and hepatocarcinogenesis $[48,49]$. Further, transient depletion of Runx1/Runx1t1 by RNA interference delayed tumor formation in vivo [50].

In summary, the global gene expression changes of malignant transformed rat hepatic stem-like cells by AFB1 significantly occurred. It was found that differently expressed genes altered markedly did not function alone, but rather associated and cooperated. Significant alterations were observed in focal adhesion, regulation of actin cytoskeleton, TGF-beta signaling pathway, MAPK signaling pathway, ECM-receptor interaction and chemokine signaling pathway. A few DEGs involved in these pathways had dose dependence, including Cav2, Itgb3, Ccl2, Cx3cl1, Pdgfrb and Tmsb4x. These results would provide some clues for understanding mechanism associated with aflatoxin-induced carcinogenesis.

Acknowledgments: We would like to thank Dr. Shen Hong (Medical Research Centre, Central South University, Hunan, China) for kindly providing WB-F344 cells.

\section{References}

[1] BOSCH FX, RIBES J, CLERIES R, DIAZ M Epidemiology of hepatocellular carcinoma. Clin Liver Dis 2005; 9: 191-211. http://dx.doi.org/10.1016/j.cld.2004.12.009

[2] LIU Y, WU F Global burden of aflatoxin-induced hepatocellular carcinoma: a risk assessment. Environ Health Perspect 2010; 118: 818-824. http://dx.doi.org/10.1289/ ehp.0901388

[3] IARC Some naturally occurring substances: food items and constituents, heterocyclic aromatic amines and mycotox- ins. IARC Monogr Eval Carcinog Risk Chem Hum 1993; 397-444.

[4] GROOPMAN JD, SCHOLL P, WANG JS Epidemiology of human aflatoxin exposures and their relationship to liver cancer. Prog Clin Biol Res 1996; 395: 211-222.

[5] BRESSAC B, KEW M, WANDS J, OZTURK M Selective G to T mutations of p53 gene in hepatocellular carcinoma from southern Africa. Nature 1991; 350: 429-431.http://dx.doi. org/10.1038/350429a0

[6] ROSKAMS TA, LIBBRECHT L and DESMET VJ Progenitor cells in diseased human liver. Semin Liver Dis 2003; 23: 385-396. http://dx.doi.org/10.1055/s-2004-815564

[7] ROSKAMS T Liver stem cells and their implication in hepatocellular and cholangiocarcinoma. Oncogene 2006; 25: 3818-3822. http://dx.doi.org/10.1038/sj.onc.1209558

[8] TSAO MS, SMITH JD, NELSON KG, GRISHAM JW A diploid epithelial cell line from normal adult rat liver with phenotypic properties of ,oval' cells. Exp Cell Res 1984; 154: 38-52. http:// dx.doi.org/10.1016/0014-4827(84)90666-9

[9] BREDFELDT TG, JAGADISH B, EBLIN KE, MASH EA, GANDOLFI AJ Monomethylarsonous acid induces transformation of human bladder cells. Toxicol Appl Pharmacol 2006; 216: 69-79. http://dx.doi.org/10.1016/j.taap.2006.04.011

[10] HUANG DA W, SHERMAN BT, LEMPICKI RA Systematic and integrative analysis of large gene lists using DAVID bioinformatics resources. Nat Protoc 2009; 4: 44-57.

[11] HUANG DA W, SHERMAN BT, LEMPICKI RA Bioinformatics enrichment tools: paths toward the comprehensive functional analysis of large gene lists. Nucleic Acids Res 2009; 37: 1-13. http://dx.doi.org/10.1093/nar/gkn923

[12] ASHBURNER M, BALL CA, BLAKE JA, BOTSTEIN D, BUTLER $H$, et al. Gene ontology: tool for the unification of biology. Nat Genet 2000; 25: 25-29. http://dx.doi.org/10.1038/75556

[13] OgATA H, GOTO S, SATO K, FUJiBUCHI W, BONO H, et al. KEGG: Kyoto Encyclopedia of Genes and Genomes. Nucleic Acids Res 1999; 27: 29-34. http://dx.doi.org/10.1093/ nar/27.1.29

[14] CHIBA T, ZHENG YW, KITA K, YOKOSUKA O, SAISHO H, et al. Enhanced self-renewal capability in hepatic stem/progenitor cells drives cancer initiation. Gastroenterology 2007; 133: 937-950. http://dx.doi.org/10.1053/j.gastro.2007.06.016

[15] SUZUKI A, SEKIYA S, ONISHI M, OSHIMA N, KIYONARI $\mathrm{H}$, et al. Flow cytometric isolation and clonal identification of self-renewing bipotent hepatic progenitor cells in adult mouse liver. Hepatology 2008; 48: 1964-1978. http://dx.doi. org/10.1002/hep.22558

[16] Dumble ML, Croager EJ, Yeoh GCT, Quail EA Generation and characterization of p53 null transformed hepatic progenitor cells: oval cells give rise to hepatocellular carcinoma. Carcinogenesis 2002; 23: 435-445. http://dx.doi.org/10.1093/ carcin/23.3.435

[17] YAM JW, TSE EY, NG IO Role and significance of focal adhesion proteins in hepatocellular carcinoma. J Gastroenterol Hepatol 2009; 24: 520-530. http://dx.doi.org/10.1111/j.14401746.2009.05813.x

[18] WIECHEN K, DIATCHENKO L, AGOULNIK A, SCHARFF $\mathrm{KM}$, SCHOBER H, et al. Caveolin-1 is down-regulated in 
human ovarian carcinoma and acts as a candidate tumor suppressor gene. Am J Pathol 2001; 159: 1635-1643. http://dx.doi. org/10.1016/S0002-9440(10)63010-6

[19] FIUCCI G, RAVID D, REICH R, LISCOVITCH M Caveolin-1 inhibits anchorage-independent growth, anoikis and invasiveness in MCF-7 human breast cancer cells. Oncogene 2002; 21: 2365-2375. http://dx.doi.org/10.1038/ sj.onc. 1205300

[20] MONGROO PS, JOHNSTONE CN, NARUSZEWICZ I, LEUNG-HAGESTEIJN C, SUNG RK, et al. Beta-parvin inhibits integrin-linked kinase signaling and is downregulated in breast cancer. Oncogene 2004; 23: 8959-8970. http://dx.doi. org/10.1038/sj.onc. 1208112

[21] SALGIA R, LI JL, EWANIUK DS, WANG YB, SATTLER M, et al. Expression of the focal adhesion protein paxillin in lung cancer and its relation to cell motility. Oncogene 1999; 18: 67-77. http://dx.doi.org/10.1038/sj.onc. 1202273

[22] SCIBELLI A, D‘ANGELO D, PELAGALli A, TAFURI S, AVALLONE L, et al. Expression levels of the focal adhesionassociated proteins paxillin and p130CAS in canine and feline mammary tumors. Vet Res 2003; 34: 193-202. http://dx.doi. org/10.1051/vetres:2002066

[23] LAMBRECHTS A, VAN TROYS M, AMPE C The actin cytoskeleton in normal and pathological cell motility. Int J Biochem Cell Biol 2004; 36: 1890-1909. http://dx.doi. org/10.1016/j.biocel.2004.01.024

[24] KWIATKOWSKI DJ Functions of gelsolin: motility, signaling, apoptosis, cancer. Curr Opin Cell Biol 1999; 11: 103-108. http://dx.doi.org/10.1016/S0955-0674(99)80012-X

[25] ZINDY PJ, L'HELGOUALC'H A, BONNIER D, LE BECHEC A, BOURD-BOITIN K, et al. Upregulation of the tumor suppressor gene menin in hepatocellular carcinomas and its significance in fibrogenesis. Hepatology 2006; 44: 1296-1307. http://dx.doi.org/10.1002/hep. 21367

[26] HSIAO HL, WANG WS, CHEN PM, SU Y Overexpression of thymosin beta- 4 renders SW480 colon carcinoma cells more resistant to apoptosis triggered by FasL and two topoisomerase II inhibitors via downregulating Fas and upregulating Survivin expression, respectively. Carcinogenesis 2006; 27: 936-944. http://dx.doi.org/10.1093/carcin/bgi316

[27] ELLIOTT RL, BLOBE GC Role of transforming growth factor Beta in human cancer. J Clin Oncol 2005; 23: 2078-2093. http://dx.doi.org/10.1200/JCO.2005.02.047

[28] ROTH-EICHHORN S, HEITMANN B, FLEMMING P, KUBICKA S, TRAUTWEIN C Evidence for the decreased expression of the latent TGF-beta binding protein and its splice form in human liver tumours. Scand J Gastroenterol 2001; 36: 1204-1210. http://dx.doi.org/ $\underline{10.1080 / 00365520152584851}$

[29] KAMALIAN L, GOSNEY JR, FOROOTAN SS, FOSTER CS, BAO ZZ, et al. Increased expression of Id family proteins in small cell lung cancer and its prognostic significance. Clin Cancer Res 2008; 14: 2318-2325. http://dx.doi.org/10.1158/ 1078-0432.CCR-07-4716

[30] YUEN HF, CHUA CW, CHAN YP, WONG YC, WANG X, et al. Id proteins expression in prostate cancer: high-level expression of Id-4 in primary prostate cancer is associated with development of metastases. Mod Pathol 2006; 19: 931-941. http://dx.doi.org/10.1038/modpathol.3800602

[31] SARGIANNIDOU I, ZHOU J, TUSZYNSKI GP The role of thrombospondin-1 in tumor progression. Exp Biol Med (Maywood) 2001; 226: 726-733.

[32] ALARMO EL, KALLIONIEMI A Bone morphogenetic proteins in breast cancer: dual role in tumourigenesis? Endocr Relat Cancer 2010; 17: 123-139. http://dx.doi.org/10.1677/ ERC-09-0273

[33] GRUSCH M, DRUCKER C, PETER-VOROSMARTY B, ERLACH N, LACKNER A, et al. Deregulation of the activin/ follistatin system in hepatocarcinogenesis. J Hepatol 2006; 45: 673-680. http://dx.doi.org/10.1016/j.jhep.2006.06.014

[34] HUANG P, HAN J, HUI L MAPK signaling in inflammationassociated cancer development. Protein Cell 2010; 1:218-226. http://dx.doi.org/10.1007/s13238-010-0019-9

[35] WAGNER EF, NEBREDA AR Signal integration by JNK and p38 MAPK pathways in cancer development. Nat Rev Cancer 2009; 9: 537-549. http://dx.doi.org/10.1038/nrc2694

[36] DAS M, GARLICK DS, GREINER DL, DAVIS RJ The role of JNK in the development of hepatocellular carcinoma. Genes Dev 2011; 25: 634-645. http://dx.doi.org/10.1101/ gad.1989311

[37] CALOCA MJ, ZUGAZA JL, BUSTELO XR Exchange factors of the RasGRP family mediate Ras activation in the Golgi. J Biol Chem 2003; 278: 33465-33473. http://dx.doi.org/10.1074/jbc. M302807200

[38] COSTANTINI S, DI BERNARDO G, CAMMAROTA M, CASTELLO G, COLONNA G Gene expression signature of human HepG2 cell line. Gene 2013; 518: 335-345. http:// dx.doi.org/10.1016/j.gene.2012.12.106

[39] FIJNEMAN RJ, PEHAM JR, VAN DE WIEL MA, MEIJER GA, MATISE I, et al. Expression of Pla2g2a prevents carcinogenesis in Muc2-deficient mice. Cancer Sci 2008; 99: 2113-2119. http://dx.doi.org/10.1111/j.13497006.2008.00924.x

[40] YANG H, ROUSE J, LUKES L, LANCASTER M, VEENSTRA $T$, et al. Caffeine suppresses metastasis in a transgenic mouse model: a prototype molecule for prophylaxis of metastasis. Clin Exp Metastasis 2004; 21: 719-735. http://dx.doi. org/10.1007/s10585-004-8251-4

[41] WU Y, ZUO J, JI G, SAIYIN H, LIU X, et al. Proapoptotic function of integrin beta(3) in human hepatocellular carcinoma cells. Clin Cancer Res 2009; 15: 60-69. http://dx.doi. org/10.1158/1078-0432.CCR-08-1028

[42] SHIBUTA K, MORI M, SHIMODA K, INOUE H, MITRA $\mathrm{P}$, et al. Regional expression of CXCL12/CXCR4 in liver and hepatocellular carcinoma and cell-cycle variation during in vitro differentiation. Jpn J Cancer Res 2002; 93: 789-797. http://dx.doi.org/10.1111/j.1349-7006.2002.tb01321.x

[43] TANG L, HU HD, HU P, LAN YH, PENG ML, et al. Gene therapy with CX3CL1/Fractalkine induces antitumor immunity to regress effectively mouse hepatocellular carcinoma. Gene Ther 2007; 14: 1226-1234. http://dx.doi.org/10.1038/ si.gt.3302959

[44] SGADARI C, ANGIOLILLO AL, CHERNEY BW, PIKE SE, FARBER JM, et al. Interferon-inducible protein-10 identi- 
fied as a mediator of tumor necrosis in vivo. Proc Natl Acad Sci USA 1996; 93: 13791-13796. http://dx.doi.org/10.1073/ pnas.93.24.13791

[45] BENGOCHEA A, DE SOUZA MM, LEFRANCOIS L, LE ROUX E, GALY O, et al. Common dysregulation of Wnt/Frizzled receptor elements in human hepatocellular carcinoma. Br J Cancer 2008; 99: 143-150. http://dx.doi.org/10.1038/sj.bjc.6604422

[46] MERRITT MA, PARSONS PG, NEWTON TR, MARTYN AC, WEBB PM, et al. Expression profiling identifies genes involved in neoplastic transformation of serous ovarian cancer. BMC Cancer 2009; 9: 378. http://dx.doi.org/10.1186/1471-2407-9-378

[47] ROOSE J, HULS G, VAN BEEST M, MOERER P, VAN DER HORN K, et al. Synergy between tumor suppressor APC and the beta-catenin-Tcf4 target Tcf1. Science 1999; 285: $1923-$ 1926. http://dx.doi.org/10.1126/science.285.5435.1923
[48] SAKAKURA C, HAGIWARA A, MIYAGAWA K, NAKASHIMA S, YOSHIKAWA T, et al. Frequent downregulation of the runt domain transcription factors RUNX1, RUNX3 and their cofactor CBFB in gastric cancer. Int J Cancer 2005; 113: 221-228. http://dx.doi.org/10.1002/ijc.20551

[49] MIYAGAWA K, SAKAKURA C, NAKASHIMA S, YOSHIKAWA T, KIN S, et al. Down-regulation of RUNX1, RUNX3 and CBFbeta in hepatocellular carcinomas in an early stage of hepatocarcinogenesis. Anticancer Res 2006; 26: 3633-3643.

[50] MARTINEZ SN, TUSSIWAND R, ZIEGLER P, MANZ MG, HEIDENREICH O Transient depletion of RUNX1/ RUNX1T1 by RNA interference delays tumour formation in vivo. Leukemia 2009; 23: 188-190. http://dx.doi.org/10.1038/ leu.2008.157 